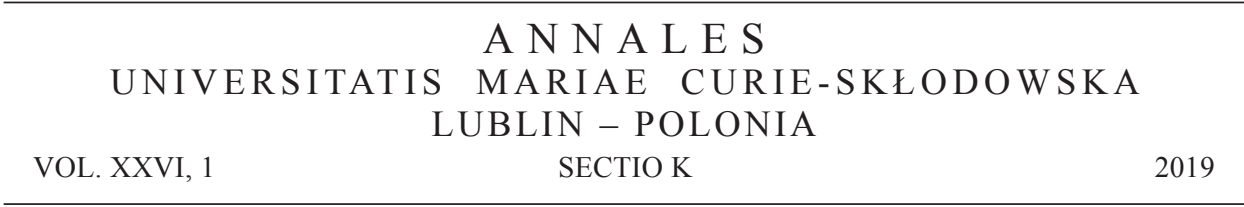

Uniwersytet Zielonogórski. Instytut Politologii

RYSZARD MICHALAK

ORCID: http://orcid.org/0000-0002-7996-5432

Polityka wyznaniowa. Zakres zjawiska

Religious Policy. The Extent of the Phenomenon

\begin{abstract}
ABSTRAKT
Celem artykułu jest zdefiniowanie polityki wyznaniowej oraz ustalenie zakresu występowania tego zjawiska. Towarzyszy temu prezentacja najważniejszych uwarunkowań (wewnętrznych i zewnętrznych), profilów polityki wyznaniowej (koncesja, reglamentacja i likwidacja) oraz prawidłowości w jej obszarze. Poza podmiotowością państwa - jako głównego twórcy i realizatora polityki wyznaniowej - w takiej roli można odnaleźć także: organizacje międzynarodowe, podmioty samorządowe, związki religijne oraz podmioty wewnątrzkonfesyjne (frakcje, grupy interesu). W artykule podjęto również próbę zarysowania najważniejszych zależności między polityką wyznaniową państwa, jego strukturą religijną oraz zróżnicowanym podłożem systemowym i ustrojowym. Rozważania umiejscowiono w kontekście refleksji naukowej na gruncie politologii religii.
\end{abstract}

Słowa kluczowe: polityka wyznaniowa, polityka religijna, politologia religii, polityka wyznaniowa koncesji, polityka wyznaniowa reglamentacji, polityka wyznaniowa likwidacji

\title{
WSTĘP
}

Studia nad polityką wyznaniową przez lata były domeną przedstawicieli nauk prawnych, którzy zgłębiali jej naturę w relacji do podmiotowego prawa wyznaniowego. Najczęściej w kontekstowych badaniach występowały one także w pracach historyków, którzy w analizie stosunków państwowo-religijnych poszukiwali możliwości wyjaśnienia szerszych zjawisk. Taka tendencja dotyczyła zarówno nauki światowej, jak i polskiej. W Polsce - za wzorcem radzieckim - dodatkowo polityka 
wyznaniowa jako przedmiot badań zwróciła w latach 70. XX wieku uwagę także filozofów i religioznawców (w tym praktyków - decydentów z Urzędu do Spraw Wyznań), którzy konceptualizację w jej obszarze wiązali ściśle z marksistowskimi wyznacznikami ideologicznymi, skutkiem czego twórczość ta jest postrzegana często jako usługowa wobec bezwzględnie obowiązującego wówczas monizmu ideologicznego.

Względnie niedawno polityka wyznaniowa stała się obszarem rosnących zainteresowań badaczy reprezentujących nauki o polityce, a aktualnie w rozszerzonej formule - nauki o polityce i administracji. Szczególna rola w tym względzie przypadła przedstawicielom politologii religii [Grott 2000; Marczewska-Rytko 2010, 2016; Burgoński, Gierycz 2014: 19-24; Michalak 2014b: 5-11; Góra-Szopiński 2015: 13-31; Marczewska-Rytko, Maj 2018]. Pod tą nazwą (ang. political science of religion lub politology of religion) skrywa się - w najbardziej popularnej wykładni [Jevtić 2007: 59-69; Jevtić 2008] - ogół badań uwzględniających różnorodne sprzężenia zjawisk religii i polityki na podstawie mariażu wielu dyscyplin nauki i ich metod, a w szczególności: nauk o polityce i administracji, nauk o kulturze i religii, nauk teologicznych, nauk socjologicznych, filozofii, historii, nauk prawnych, prawa kanonicznego, ekonomii i geografii społeczno-ekonomicznej. W znaczeniu właściwym dziedzinie nauk społecznych definiowana jest jako subdyscyplina nauk o polityce i administracji, której istotą jest politologiczna analiza zjawiska religii lub któregokolwiek z jej komponentów (doktryna, kult, organizacja religijna). W takim przypadku podstawowym założeniem jest postrzeganie religii jako zjawiska politycznego - analogicznie do założeń socjologii religii, która widzi w religii zjawisko społeczne [Weber 1963; Hamilton 2012: 1-20]. Inna egzegeza odnosząca się do usytuowania politologii religii pośród subdyscyplin nauk o polityce i administracji zakłada, że jej treść obejmuje kwestie wzajemnego oddziaływania zjawisk religijnych i politycznych, a wyjściową perspektywą badawczą są ustalenia nauk o polityce i administracji przy odwołaniu do metod i zdobyczy innych dyscyplin nauki. Politologia religii w najwęższym rozumieniu to z kolei badania politologiczne nad religią na podstawie paradygmatu funkcji czynnika politycznego w religii [Michalak 2018a: 344-348]. Należy również podkreślić za Kazimierzem Bankiem, Bogumiłem Grottem, Olgierdem Grottem oraz Marią Marczewską-Rytko, że politologia religii rozwija się także jako subdyscyplina religioznawstwa [Banek 2001: 77-82; Grott, Grott 2015: 7; Marczewska-Rytko 2018: 17-33].

POLITYKA WYZNANIOWA - DEFINICJA I ZAKRES ZJAWISKA

W perspektywie politologii religii ,polityka wyznaniowa” to przede wszystkim szczegółowy rodzaj polityki publicznej państwa, który jest ukierunkowany na aktywność związków wyznaniowych (związków religijnych lub organizacji religijnych) [Michalak 2018b: 355-357]. Według Michała Pietrzaka, ,związek wyznaniowy” to z kolei „specyficzny typ zorganizowanej społeczności ludzkiej, posiadający określony ustrój wewnętrzny, zdolny do wytworzenia organów władzy, spełniających 
funkcje wewnętrzne i reprezentujących związek na zewnątrz oraz uprawnionych do określania praw i obowiązków swoich członków" [Pietrzak 1995: 9]. Celem jego istnienia jest realizacja „potrzeb religijnych” wyznawców. Związki wyznaniowe „różnią się między sobą odrębnością dogmatów wiary, obrzędów oraz praktyk religijnych" [Tunia 2016: 34-35]. Istotą polityki wyznaniowej jest zatem kształtowanie relacji państwa z poszczególnymi związkami religijnymi, jak również wpływanie na stosunki pomiędzy nimi.

Odnosząc się do nazewnictwa występującego w narracjach naukowych, należy podkreślić, że określeniem alternatywnym do „polityki wyznaniowej” (ang. confessional policy) jest mniej popularna w Polsce [Góra-Szopiński 2017: 9-29], a nader powszechna w opracowaniach zachodnich nazwa polityka religijna - ang. religious policy [Fagan 2013; Gerster, Van Melis, Willems 2018]. Podobnie „Związek wyznaniowy” jest pojęciem znacznie częściej stosowanym, aniżeli „Związek religijny” i „organizacja religijna”. Kategorie religii i wyznania nie są natomiast w swojej istocie synonimiczne (wyznanie zawiera się w religii). Warto rozważyć także możliwość rozróżnienia pomiędzy związkiem wyznaniowym jako terminem prawnym a organizacją religijną jako określeniem socjologicznym i politologicznym.

Szerokie spojrzenie na politykę wyznaniową dopuszcza perspektywę, w której aparat państwa podejmuje określone działania wobec podmiotów związanych - bezpośrednio lub pośrednio - z organizacjami religijnymi, właśnie z powodu tej więzi. Mogą być nimi partie religijne (np.: izraelska Miflaga Datit Leumi, francuski Union des Démocrates Musulmans, indyjska Bharatiya Janata Party), partie odwołujące się do religii (w nazwie, programie lub deklaracji ideowej, np. niemieckie: Christlich Demokratische Union i Christlich Soziale Union), a także stowarzyszenia, fundacje, wydawnictwa i redakcje czasopism oraz inne zorganizowane formy społecznej aktywności (np. polskie organizacje dobroczynne: rzymskokatolicki Caritas, prawosławny Eleos i ewangelicka Diakonia), które mają konotację religijną i, co może ważniejsze, jako religijne są postrzegane w przestrzeni publicznej. W szczególnych przypadkach stroną polityki wyznaniowej mogą być także pojedynczy ludzie związani z życiem religijnym.

Jak zauważył Józef Krukowski, poza zasadami i celami, ,jakimi władze państwowe kierują się w stosunku do religii i wyznań religijnych", drugim filarem polityki wyznaniowej są „metody (środki), jakimi posługują się dla ich urzeczywistniania w życiu społecznym" [Krukowski 2002: 5]. Maria Libiszowska-Żółtkowska podkreśliła ponadto, że ,polityka wyznaniowa spełnia funkcje: normatywną i kontrolną nad instytucjami religijnymi, definiuje charakter relacji między państwem a obecnymi na jego terytorium kościołami i związkami wyznaniowymi” [Libiszowska-Żółtkowska 2018: 266]. Rozwijając te spojrzenia, można przyjąć, że na politykę wyznaniową państwa składają się działania o charakterze: koncepcyjnym, programowym, operacyjnym i wykonawczym, realizowane przez specjalistyczne podmioty władzy państwowej wobec podmiotów religijnych. W warunkach państwa demokratycznego są to instytucje administracyjne (samodzielne, np. w postaci urzędu lub ministerstwa, bądź stanowiące 
element szerszej struktury, np. departament w ramach ministerstwa) i służby specjalne (np. monitorujące działalność fundamentalistów religijnych lub sekty destrukcyjne). W państwach autorytarnych i totalitarnych podmiot realizujący politykę wyznaniową może być bardziej złożony, gdyż obok struktur państwowych status decydencki mają tam zwykle także struktury partyjne, a większą rolę odgrywają również rozbudowane służby specjalne [Leszczyński 2004: 347-356; Michalak 2014a].

Politologiczna konceptualizacja w obszarze polityki wyznaniowej jest związana z ustaleniami innych dyscyplin nauki [Dudra, Król-Mazur, Maj 2018], a w szczególności nauk prawnych w odniesieniu do prawa wyznaniowego i właściwego dla tej dyscypliny określenia modelowego relacji państwo-organizacje religijne. Jest to również optyka uwzględniająca zróżnicowanie kompetencji - prawnych i politycznych - decydentów odpowiedzialnych za sektor polityki wyznaniowej. Komplementarna perspektywa badawcza, łącząca metody nauk prawnych z metodami nauk o polityce i administracji, wydaje się dla takiej eksploracji nieodzowna, gdyż z jednej strony prawo wyznaniowe jest na ogół wyrazem określonej polityki [Pietrzak 2010: 365], a z drugiej realna polityka wyznaniowa nie zawsze mieści się wyłącznie w porządku formalno-prawnym.

\section{UWARUNKOWANIA POLITYKI WYZNANIOWEJ}

Polityka wyznaniowa jest warunkowana wieloma czynnikami, które można zgrupować w podziale na wewnętrzne i zewnętrzne.

W pierwszej grupie szczególne znaczenie mają:

1) specyfika oraz struktura religijna i wyznaniowa państwa;

2) wielkość populacji państwa deklarującej ateizm, agnostycyzm, apateizm lub indyferentyzm religijny;

3) proporcje między sakralizacją a sekularyzacją przestrzeni publicznej;

4) ustrój, system polityczny oraz ideologia obowiązująca lub dominująca w państwie;

5) pragmatyka rywalizacji politycznej w wariancie umożliwiającym instrumentalizację/polityzację religii;

6) prawny i systemowy model wyznaniowy państwa;

7) potencjał wywierania wpływu przez związki wyznaniowe na decydentów państwowych;

8) potrzeba religijnej legitymizacji władzy przez decydentów;

9) osobiste przekonania oraz zaangażowanie religijne decydentów państwowych;

10) zależności między identyfikacjami: etnokulturową i wyznaniową.

Z kolei wśród czynników zewnętrznych szczególną rolę spełniają:

1) względy bezpieczeństwa państwa (różnie definiowane i instrumentalizowane);

2) charakter religii (w liczbie pojedynczej lub mnogiej) występujących w sąsiedztwie państwa; 
3) struktura religijna oraz wyznaniowa ościennych państw (w tym status mniejszości związanych z rzeczonym państwem);

4) charakter polityki wyznaniowej występującej w otoczeniu międzynarodowym;

5) uwarunkowania geopolityczne regionu (występowanie lub brak ,geopolityki sakralnej”, ,polityki meczetowej” etc.);

6) międzynarodowe normy prawne, w których dane państwo partycypuje lub opiera przed ich oddziaływaniem;

7) skala i charakter międzynarodowego ,usieciowienia” danej wspólnoty religijnej;

8) występowanie lub brak konfliktów religijnych w otoczeniu międzynarodowym;

9) występowanie lub brak tendencji proekumenicznych wśród podmiotów religijnych regionu;

10) rzeczywiste, a nie tylko deklarowane znaczenie irenologii w przekazie związków religijnych w regionie.

We współczesnej Europie najnowszym czynnikiem, który występuje w obu zbiorach, a który może realnie wpływać na kierunki polityki wyznaniowej niemal wszystkich państw, są nowe trendy migracyjne [Gierycz 2016: 73-84; Wojtaszczyk, Szymańska 2017; Pochyły 2017: 113-128; Wójcik 2018; Husar-Poliszuk, Secler, Ślusarczyk 2018; Dudała 2018: 181-197] oraz towarzysząca im presja unijnych decydentów na obieranie multikulturowego modelu organizacji społecznej przez państwa członkowskie Unii Europejskiej [Bock-Côté 2017]. To tylko potwierdza te naukowe ustalenia, które głoszą, iż polityka wyznaniowa pozostaje najczęściej w ścisłym związku z polityką narodowościową lub etniczną [Zenderowski 2011; 2016: 29-51; Dudra 2018; 2019].

Polityka wyznaniowa państwa jest najczęściej rozpatrywana jako składowa polityki wewnętrznej, jednakże z powodzeniem bywa też ważnym komponentem polityki zagranicznej, o czym współcześnie przekonują choćby „,polityka meczetowa” Turcji [Sulkowski 2016: 241-255] lub rosyjska polityka promocji idei Moskwy Trzeciego Rzymu [Michalak 2004: 91-105].

\section{PODMIOTOWOŚĆ POLITYKI WYZNANIOWEJ}

Polityka wyznaniowa jest domeną państwa, ale może dotyczyć także innego typu podmiotów. Analizując chociażby prawo i działania Unii Europejskiej [Orzeszyna 2007; Mazurkiewicz, Ptaszek, Młyńczyk 2018] lub Organizacji Współpracy Islamskiej [Gieryńska 2017; Woźniak-Bobińska, Solarz 2018] w odniesieniu do sfery religijnej można wyszczególnić kategorię polityki wyznaniowej organizacji międzynarodowej. W kierunku odwrotnym - nie na zewnątrz, ale wewnątrz struktury państwa - dostrzec można natomiast regionalną/lokalną/ samorządową politykę wyznaniową [Mierzwa 2014: 7-22]. W warunkach pluralizmu religijnego 
własną politykę wyznaniową może kreować także dany związek wyznaniowy wobec innych związków wyznaniowych, np. zawierając koalicje i sojusze z jednymi organizacjami religijnymi oraz/lub prowadząc rywalizację z innymi - w wymiarze krajowym i międzynarodowym [Górzna 2015: 291-312; Maj 2016; Kulska 2016: 81-101; Abdalla 2017: 193-207]. W takim wypadku mowa o polityce wyznaniowej związku religijnego. W specyficznych warunkach hierokracji państwowej lub totalnej teokracji polityka wyznaniowa państwa oraz polityka wyznaniowa dominującego związku wyznaniowego są w praktyce zbieżne. Pozostając przy perspektywie związku wyznaniowego jako podmiotu koncepcyjnego i operacyjnego w obszarze swoich wpływów, o jego polityce wyznaniowej można mówić także w odniesieniu do działań kreowanych, np. w celu rozstrzygania o kwestiach spornych, które mogą zachodzić w relacjach pomiędzy przedstawicielami różnych wewnątrzkonfesyjnych podmiotów. Te ostatnie - frakcje, grupy interesów, pojedynczy ludzie - są w takim kontekście de facto również podmiotami polityki wyznaniowej [Potz 2016; Kowalczyk 2016; 2017: 71-84]. Zważywszy na takie okoliczności, ,polityka wyznaniowa” może zatem oznaczać politykę dowolnych podmiotów społecznych ukierunkowaną na związki wyznaniowe (związki religijne lub organizacje religijne). Owe podmioty społeczne stają się wówczas - nolens volens - podmiotami politycznymi.

\section{KIERUNKI POLITYKI WYZNANIOWEJ}

Badanie polityki wyznaniowej na podstawie kryterium aprobaty/dezaprobaty państwa wobec związków wyznaniowych pozwala wyróżnić trzy wyraźne kierunki (profile, odmiany). Są nimi:

a) polityka wyznaniowa koncesji, która oznacza praktycznie nieograniczoną i wspieraną lub co najmniej akceptowaną przez państwo i pozbawioną ingerencji z jego strony działalność związku religijnego;

b) reglamentacyjna polityka wyznaniowa, która niesie przyzwolenie państwa na działalność związków wyznaniowych, ukierunkowaną na wiernych własnej wspólnoty oraz - w wersji nierestrykcyjnej - zgodę na limitowaną aktywność zewnętrzną; w wersji radykalnej występuje głęboka reglamentacja, która oznacza przyzwolenie tylko na niewielką część praktyk religijnych lub na taką wersję nauczania religijnego, która jest okrojona z treści sprzecznych z linią państwa;

c) likwidacyjna polityka wyznaniowa, w której zawierają się działania państwa ukierunkowane na przeciwdziałanie negatywnie ocenianym tendencjom i zjawiskom występującym w działalności organizacji religijnej lub nawet dążenia do prawnej delegalizacji i pełnej likwidacji organizacji religijnej.

Wydaje się, że najważniejszym wyzwaniem, jakie w tym kontekście stoi przed politologią religii, jest ustalenie zależności pomiędzy tymi kierunkami a strukturą religijną, podłożem systemowym i ustrojowym państw, typem reżimu politycznego oraz modelem stosunków państwo-związki wyznaniowe. W tej kombinacji zapropo- 
nować można (w perspektywie XX i XXI wieku) - alternatywnie do innych typologii [Borecki: 159-209; Sowiński 2008: 39-52; Orzeszyna 2007: 63-228; Leszczyński 2011: 44-54] - dziesięć kategorii państw [Zenderowski, Michalak 2018]:

1. Państwo demokratyczne, świeckie i przyjazne wobec związków wyznaniowych w formule miękkiej separacji lub separacji skoordynowanej (np. współczesne Niemcy).

2. Państwo demokratyczne, świeckie i w pełni zdystansowane wobec zjawiska religii w formule separacji wrogiej (np. współczesna Francja).

3. Państwo demokratyczne i zarazem wyznaniowe de iure (np. współczesne: Dania, Cypr, Grecja, Wielka Brytania).

4. Państwo demokratyczne i zarazem wyznaniowe de facto (kategoria najbardziej spekulatywna, oparta na domniemaniu, np. współczesny Izrael).

5. Państwo hybrydowe i wyznaniowe de facto (np. współczesne: Rosja, Armenia, Turcja).

6. Państwo autokratyczne i wyznaniowe (np. Hiszpania w okresie rządów Franco, Portugalia w okresie rządów Salazara, współczesne: Mjanma, Arabia Saudyjska).

7. Państwo autokratyczne i laickie (np. Turcja w okresie rządów Atatürka, współczesne Chiny).

8. Państwo teokratyczne/hierokratyczne (np. współczesny Iran, Watykan).

9. Totalna teokracja (np. Państwo Islamskie, Emirat Kaukaski).

10. Państwo totalitarne kreujące parareligię (np. były Związek Radziecki, Chiny epoki Mao, współczesna Korea Północna).

\section{GŁÓWNE PRAWIDŁOWOŚCI POLITYKI WYZNANIOWEJ}

Analiza polityki wyznaniowej, którą zawarłem w rozdziale III monografii Polityka wyznaniowa. Aspekty teoretyczne i egzemplifikacje [Zenderowski, Michalak 2018: 67-151, rozdz. III] na podstawie przykładów kilkudziesięciu państw (z różnych kręgów kulturowo-religijnych), pozwala uchwycić kilka prawidłowości, które naturalnie wymagają dalszych i pogłębionych studiów:

1. Polityki wyznaniowe: koncesji, reglamentacji i likwidacji, występują jednocześnie we wszystkich państwach. Dzieje się tak niezależnie od ich ustroju i reżimu politycznego, a nawet niezależnie od ogólnego modelu relacji państwo-związki wyznaniowe.

2. Czynniki systemowe wpływają jednakże na skalę i poziom natężenia każdej z odmian polityki wyznaniowej. W odniesieniu do podstawowego podziału na państwa demokratyczne i niedemokratyczne, można zauważyć dominację polityk koncesji akceptacji i reglamentacji w pierwszej grupie państw oraz przewagę polityk koncesji wsparcia i likwidacji w drugiej.

3. Rozwiązania środkowe - oparte na akceptacji i nierestrykcyjnej reglamentacji - są swoistym barometrem równowagi społecznej w państwie, w którym wierzący i niewierzący są równoprawnymi gospodarzami tej samej przestrzeni publicznej. 
4. Koincydencja polityk krańcowych - koncesji bezgranicznego wsparcia i bezwzględnej likwidacji - występuje w skrajnie niedemokratycznych typach państw: totalnej teokracji oraz państwach totalitarnych, które zarazem kreują fenomeny parareligijne.

5. Polityka wyznaniowa głębokiej reglamentacji występuje często jako pretekst służący odrzuceniu przez państwo posądzeń o prześladowania i nietolerancję religijną. Głęboka reglamentacja najczęściej nie różni się od polityki likwidacyjnej.

6. O przewadze określonego $\mathrm{w}$ danym państwie kierunku polityki wyznaniowej decyduje również charakter samych religii, które w nim dominują, a także profil organizacji religijnych, które są nośnikami tychże religii.

7. Zjawisko kompatybilności i kolizyjności celów państw i związków wyznaniowych to w znacznym stopniu efekt jedności lub zderzenia porządków aksjologicznych - zbieżnych albo konkurencyjnych - reprezentowanych przez oba typy podmiotów.

8. Poza uwarunkowaniami ideologicznymi powodem wybrania określonego kierunku polityki wyznaniowej jest stanowisko decydentów państwowych wynikające najczęściej z ich oceny organizacji religijnych, dokonanej przez pryzmat subiektywnie określonej dychotomii:

\section{A i B}

a) związek wyznaniowy społecznie pozytywny vs b) związek wyznaniowy społecznie destrukcyjny

oraz/lub w innym wariancie

\section{C i D}

c) związek wyznaniowy politycznie pożądany $v s$ d) związek wyznaniowy politycznie niepożądany

- zgodność określona przez jednoczesne występowanie cech a i c prowadzi decydentów do polityki wyznaniowej koncesji wsparcia, oznaczającej praktycznie nieograniczoną i minimalnie kontrowaną działalność związku wyznaniowego,

- ocena a, lecz bez cechy c może zrodzić politykę wyznaniową koncesji akceptacji oraz reglamentacyjną politykę wyznaniową,

- $\mathrm{w}$ wariancie b i d rozwiązaniem przyjmowanym przez decydentów politycznych jest nieuchronnie likwidacyjna polityka wyznaniowa.

9. Zauważalna jest tendencja ku polaryzacji rozwiązań systemowych podejmowanych przez państwa wobec związków religijnych. Procesy rezygnacji z modelu państwa wyznaniowego (widoczne przede wszystkim w Europie Zachodniej, w protestanckim kręgu kulturowo-religijnym) postępują równolegle do rozwiązań ku wyrazistemu państwu wyznaniowemu (w pozaeuropejskim lub granicznym kręgu kulturowo-religijnym, na gruncie: islamu, judaizmu, buddyzmu oraz prawosławia).

10. Wyznaczniki kulturowo-religijne coraz częściej aktywizują polityki zagraniczne współczesnych państw, a to nakazuje postrzegać politykę wyznaniową także poza klasycznymi jej funkcjami i ramami, tj. poza polityką wewnętrzną. 


\section{ZAKOŃCZENIE}

Polityka wyznaniowa występuje powszechnie jako szczegółowy rodzaj polityki publicznej państwa, który jest ukierunkowany na aktywność związków wyznaniowych (związków religijnych, organizacji religijnych). Coraz częściej dotyczy ona jednak także innego typu podmiotów. Z powodzeniem można wyszczególnić na przykład kategorię polityki wyznaniowej organizacji międzynarodowej oraz regionalną/lokalną/samorządową politykę wyznaniową. Zważywszy na kryterium podmiotowe (sprawcze), polityka wyznaniowa może być zatem rozumiana jako polityka podmiotów społecznych, która jest nakierowana na związki wyznaniowe. W kompleksowym wydaniu polityki wyznaniowej danego podmiotu w jej zakres wchodzą działania o charakterze: koncepcyjnym, programowym, operacyjnym i wykonawczym. Najczęściej takimi możliwościami dysponuje aparat państwowy, który ma w swoim potencjale instytucje administracyjne (samodzielne, np. w postaci urzędu lub ministerstwa, bądź stanowiące element szerszej struktury, np. departament w ramach ministerstwa) i służby specjalne (np. monitorujące działalność fundamentalistów religijnych lub sekty destrukcyjne).

Politologiczna konceptualizacja w obszarze polityki wyznaniowej jest związana z ustaleniami innych dyscyplin nauki, a w szczególności nauk prawnych w odniesieniu do prawa wyznaniowego i właściwego dla tej dyscypliny określenia modelowego relacji państwo-organizacje religijne. Komplementarna perspektywa badawcza, łącząca metody nauk prawnych z metodami nauk o polityce $\mathrm{i}$ administracji, wydaje się dla takiej eksploracji nieodzowna, gdyż z jednej strony prawo wyznaniowe jest na ogół wyrazem określonej polityki, a z drugiej realna polityka wyznaniowa nie zawsze mieści się wyłącznie w porządku formalno-prawnym. Rozszerzenie tej perspektywy o aparat naukowy właściwy religiologii, socjologii czy ekonomii pozwala dodatkowo uchwycić także liczne - ukazane w artykule - uwarunkowania (wewnętrzne i zewnętrzne) polityki wyznaniowej, a także tworzy podstawy do odnajdywania prawidłowości w jej obszarze. To z kolei przemawia za takim postrzeganiem politologii religii, które czyni ustalenia nauk o polityce i administracji wyjściową perspektywą badawczą, jednak przy koniecznym odwołaniu do metod i zdobyczy innych dyscyplin nauki.

\section{BIBLIOGRAFIA}

Abdalla, M. 2017. Unickie Kościoły Bliskiego Wschodu: polityka Watykanu wobec chrześcijan nierzymskich, [w:] Polityczne uwarunkowania religii - Religijne uwarunkowania polityki, S. Dudra, R. Michalak i Ł. Młyńczyk (red.), Pracownia Badań nad Mniejszościami Narodowymi i Etnicznymi - Instytut Politologii - Uniwersytet Zielonogórski oraz Wydawnictwo Morpho, Zielona Góra, s. 193-207.

Banek, K. 1999. Politologia religii jako dziedzina badań religioznawczych, „Przegląd Religioznawczy”, nr 3-4, s. 77-82.

Bock-Côté, M. 2017. Multikulturalizm jako religia polityczna, Wydawnictwo PAX, Warszawa. 
Borecki, P. 2015. Modele relacji między państwem a Kościołem i ich wyraz we współczesnym konstytucjonalizmie, „Mazowieckie Studia Humanistyczne”, nr 1-2, s. 159-209.

Burgoński, P., Gierycz, M. (red.) 2014. Religia i polityka. Zarys problematyki, Dom Wydawniczy Elipsa, Warszawa.

Dudała, R. 2018. Italian migration policy: change and effects, „Przegląd Nrodowościowy - Review of Nationalities", nr 8, DOI: https://doi.org/10.2478/pn-2018-0012: Nations without state or states without nations, ed. by P. Pochyły, s. 181-197.

Dudra, S. 2018. Lemko Identity and the Orthodox Church, preface by P. J. Best, Carpathian Institute Higganum and The Lemko Association, Connecticut, New Heaven 2018.

Dudra, S. 2019. Polski Autokefaliczny Kościót Prawosławny w obszarze polityki wyznaniowej i polityki narodowościowej Polski Ludowej i III Rzeczypospolitej, Wydawnictwo Scholar, Warszawa.

Dudra, S., Król-Mazur, R., Maj, D. 2018. Polityka wyznaniowa. Wschodnia i ekumeniczna perspektywa eklezjalna, Pracownia Badań nad Mniejszościami Narodowymi i Etnicznymi - Instytut Politologii Uniwersytet Zielonogórski oraz Wydawnictwo Morpho, Zielona Góra.

Fagan, G. 2013. Believing in Russia - Religious Policy after Communism, Routledge Contemporary Russia and Eastern Europe Series, Routledge, London-New York.

Gerster, D., Van Melis, V., Willems, U. (eds.) 2018. Religionspolitikheute. Problemfelder und Perspektiven in Deutschland, Herder, Freiburg.

Gierycz, M. 2016. Polska debata o imigracji w perspektywie politologii religii, „Chrześcijaństwo-ŚwiatPolityka", nr 20, s. 73-84. DOI: https://doi.org/10.21697/csp.2016.20.1.05.

Gieryńska, A. 2017. Organizacja Wspótpracy Islamskiej. Geneza, charakterystyka i działalność w regionie Bliskiego Wschodu, Wydawnictwo Scholar, Warszawa.

Góra-Szopiński, D. 2015. Czym może, a czym nie powinna być politologia religii?, [w:] Polityka jako wyraz lub następstwo religijności, R. Michalak (red.), Pracownia Badań nad Mniejszościami Narodowymi i Etnicznymi - Instytut Politologii - Uniwersytet Zielonogórski oraz Wydawnictwo Morpho, Zielona Góra, s. 13-31.

Góra-Szopiński, D. 2017. Polityka religijna na obszarze dawnej Rzeczypospolitej. Ćwiczenie z teologii politycznej, [w:] Polityczne uwarunkowania religii - Religijne uwarunkowania polityki, S. Dudra, R. Michalak, Ł. Młyńczyk (red.), Pracownia Badań nad Mniejszościami Narodowymi i Etnicznymi Instytut Politologii - Uniwersytet Zielonogórski oraz Wydawnictwo Morpho, Zielona Góra, s. 9-29.

Górzna, S. 2015. Polityczny wymiar dialogu Kościoła katolickiego z judaizmem w wybranych dokumentach Kurii Rzymskiej, „Studia Oecumenica”, t. 15, s. 291-312.

Grott, B. (red.) 2000. Religia i polityka, Wydawnictwo Uniwersytetu Jagiellońskiego, Kraków.

Grott, B., Grott, O. (red.) 2015. Wiedza religioznawcza w badaniach politologicznych, Wydawnictwo von Borowiecky, Warszawa.

Hamilton, M.B. 2012. The Sociology of Religion. Theoretical and Comparative Perspectives, Routledge, London-New York.

Husar-Poliszuk, W., Secler, B., Ślusarczyk, P.S. 2018. Polityka wyznaniowa. Konteksty innych polityk publicznych. Austria, Katalonia, Polska, Pracownia Badań nad Mniejszościami Narodowymi i Etnicznymi - Instytut Politologii - Uniwersytet Zielonogórski oraz Wydawnictwo Morpho, Zielona Góra.

Jevtić, M. 2007. Political Science and Religion, „Politics and Religion Journal”, no. 1, Belgrade, s. 59-69.

Jevtić, M. 2008. Religion and Power. Essays on Politology of Religion, Dioceze of Ras'Prizren and Kosovo-Metohija: Center for Study of Religion and Religious Tolerance, Belgrade.

Kowalczyk, K. 2016. Między antyklerykalizmem a konfesjonalizacja. Partie polityczne wobec Kościoła katolickiego w Polsce po 1989 roku, Wydawnictwo Mado, Torun.

Kowalczyk, K. 2017. Grupy interesu artykułujace postulaty Kościoła katolickiego w Polsce, [w:] Polityczne uwarunkowania religii - Religijne uwarunkowania polityki, S. Dudra, R. Michalak, Ł. Młyńczyk (red.), Pracownia Badań nad Mniejszościami Narodowymi i Etnicznymi - Instytut Politologii - Uniwersytet Zielonogórski oraz Wydawnictwo Morpho, Zielona Góra, s. 71-84.

Kulska, J. 2016. Religijne budowanie pokoju (religious peacebuilding): rola religii w rozwiazywaniu konfliktów, [w:] Religia w konfliktach etnicznych we współczesnym świecie, t. 1: Zagadnienia teoretyczne. 
Europa i obszar poradziecki, A. Szabaciuk, D. Wybranowski, R. Zenderowski (red.), Wydawnictwo KUL, Lublin, s. 81-101.

Krukowski, J. 2002. Polityka wyznaniowa państw postkomunistycznych. Główne linie, „Roczniki Nauk Prawnych", t. 12, z. 2, s. 5-19.

Leszczyński, P.A. 2004. Administracja wyznaniowa wybranych państw współczesnych-zarys zagadnienia, [w:] Prawo wyznaniowe w systemie prawa polskiego, A. Mezglewski (red.), Wydawnictwo KUL, Lublin, s. 347-356.

Leszczyński, P.A. 2011. O nową klasyfikację modeli relacji między państwem a związkami wyznaniowymi, „Przegląd Prawa Publicznego", nr 7-8 (53-54), s. 44-54.

Libiszowska-Żółtkowska, M. 2018. Polityka wyznaniowa, [w:] Nauki o polityce publicznej. Monografia dyscypliny, J. Kwaśniewski (red.), IPSiR Uniwersytet Warszawski, Warszawa, s. 266-287.

Maj, D. 2016. Konferencja Kościołów Europejskich wobec integracji europejskiej, Wydawnictwo Uniwersytetu Marii Curie-Skłodowskiej, Lublin.

Marczewska-Rytko, M. 2010. Religia i polityka w globalizującym się świecie, Wydawnictwo Uniwersytetu Marii Curie-Skłodowskiej, Lublin.

Marczewska-Rytko, M. (red.) 2016. Czynnik religijny w polityce wewnątrzpaństwowej i międzynarodowej na przełomie drugiego i trzeciego tysiąclecia, Wydawnictwo Uniwersytetu Marii Curie-Skłodowskiej, Lublin.

Marczewska-Rytko, M. 2018. Politologia religii jako subdyscyplina religioznawstwa i/lub nauk o polityce, [w:] Politologia religii, M. Marczewska-Rytko, D. Maj (red.), Wydawnictwo Uniwersytetu Marii Curie-Skłodowskiej, Lublin, s. 17-33.

Marczewska-Rytko, M., Maj, D. (red.) 2018. Politologia religii, Wydawnictwo Uniwersytetu Marii Curie-Skłodowskiej, Lublin.

Mazurkiewicz, P., Ptaszek, R., Młyńczyk, Ł. 2018. Polityka wyznaniowa. Perspektywa Unii Europejskiej, Pracownia Badań nad Mniejszościami Narodowymi i Etnicznymi - Instytut Politologii - Uniwersytet Zielonogórski oraz Wydawnictwo Morpho, Zielona Góra.

Michalak, R. 2004. Powrót koncepcji Trzeciego Rzymu, „Doctrina - Międzynarodowy Przegląd Humanistyczny", nr 1, s. 91-105.

Michalak, R. 2014a. Polityka wyznaniowa państwa polskiego wobec mniejszości religijnych $w$ latach 1945-1989, Oficyna Wydawnicza Uniwersytetu Zielonogórskiego, Zielona Góra.

Michalak, R. (red.) 2014b. Religijne determinanty polityki, Pracownia Badań nad Mniejszościami Narodowymi i Etnicznymi - Instytut Politologii - Uniwersytet Zielonogórski oraz Wydawnictwo Morpho, Zielona Góra.

Michalak, R. 2018a. Politologia religii, [w:] Leksykon wiedzy politologicznej, J. Marszałek-Kawa, D. Plecka (red.), Wydawnictwo Adam Marszałek, Toruń, s. 344-348.

Michalak, R. 2018b. Polityka wyznaniowa, [w:] Leksykon wiedzy politologicznej, J. Marszałek-Kawa, D. Plecka (red.), Wydawnictwo Adam Marszałek, Toruń 2018, s. 355-357.

Mierzwa, J. 2014. „Między starosta a plebanem”. Relacje między państwem a zwiazkami wyznaniowymi na szczeblu administracji ogólnej I instancji w okresie Drugiej Rzeczypospolitej-zarys problematyki, [w:] Państwo - religia. Instytucje państwowe i obywatele wobec religii w Europie Środkowo-Wschodniej $w X X$ wieku, J. Durka (red.), Kalisz, s. 7-22.

Orzeszyna, K. 2007. Podstawy relacji między państwem a kościołami w konstytucjach państw członkowskich i traktatach Unii Europejskiej. Studium porównawcze, Wydawnictwo KUL, Lublin.

Pietrzak, M. 1995. Prawo wyznaniowe, Wydawnictwo PWN, Warszawa.

Pietrzak, M. 2010. Polityka wyznaniowa III Rzeczypospolitej w latach 1990-2001 (próba diagnozy), „Prawo” CCCXI, seria: Acta Universitatis Wratislaviensis, nr 3270, s. 365-377.

Pochyły, P. 2017. Polska polityka zagraniczna w reakcji na trzy kryzysy w Europie-analiza 'mini' exposé ministra Witolda Waszczykowskiego z 2016 r., [w:] Pomiędzy mythos i logos społecznej zmiany, J. Golinowski, S. Sadowski (red.), Bydgoszcz, s. 113-128.

Potz, M. 2016. Teokracje amerykańskie. Źródła i mechanizmy władzy usankcjonowanej religijnie, Wydawnictwo Uniwersytetu Łódzkiego, Łódź. 
Sowiński, S. 2008. Modele stosunków państwo - Kościót w Unii Europejskiej, „Studia Europejskie”, nr 3, s. $39-52$.

Sulkowski, M. 2016. Islamska rekonkwista w Turcji, [w:] Religia w konfliktach etnicznych we wspótczesnym świecie, t. 1: Zagadnienia teoretyczne. Europa i obszar poradziecki, A. Szabaciuk, D. Wybranowski, R. Zenderowski (red.), Wydawnictwo KUL, Lublin, s. 241-255.

Tunia, A. 2016. Polityka państwa w zakresie ustalenia jednolitej siatki pojęć stosowanych w przepisach prawa wyznaniowego, [w:] Polityka wyznaniowa a prawo III Rzeczypospolitej, M. Skwarzyński, P. Steczkowski (red.), Wydawnictwo KUL, Lublin, s. 33-52.

Weber, M. 1963. The sociology of religion, Beacon series in the sociology of politics and religion, translated by E. Fischoff, introduction by T. Parsons, Beacon Press, Boston.

Wojtaszczyk, K.A., Szymańska, J. (red.) 2017. Uchodźcy w Europie. Uwarunkowania. Istota. Następstwa, Wydawnictwo Aspra JR, Warszawa.

Woźniak-Bobińska, M., Solarz, A.M. (red.) 2018. Wprowadzenie do polityki zagranicznej muzułmańskich państw Bliskiego Wschodu i Afryki Pólnocnej, Wydawnictwo Scholar, Warszawa.

Wójcik, J. 2018. Imigracja z krajów OIC do Polski w latach 2013-2018, seria: Analizy European Issues Institute, Warszawa.

Zenderowski, R. 2011. Religia a tożsamość narodowa i nacjonalizm w Europie Środkowo-Wschodniej. Między etnicyzacja religii a sakralizacją etnosu (narodu), Wydawnictwo Uniwersytetu Wrocławskiego, Wrocław.

Zenderowski, R. 2016. Konflikt etniczny, konflikt religijny, konflikt etnoreligijny jako konflikty polityczne, [w:] Religia w konfliktach etnicznych we współczesnym świecie, t. 1: Zagadnienia teoretyczne. Europa i obszar poradziecki, A. Szabaciuk, D. Wybranowski, R. Zenderowski (red.), Wydawnictwo KUL, Lublin, s. 29-51.

Zenderowski, R., Michalak, R. 2018. Polityka wyznaniowa. Aspekty teoretyczne i egzemplifikacje, Pracownia Badań nad Mniejszościami Narodowymi i Etnicznymi - Instytut Politologii - Uniwersytet Zielonogórski oraz Wydawnictwo Morpho, Zielona Góra.

\section{RELIGIOUS POLICY. THE EXTENT OF THE PHENOMENON}

Abstract: Religious policy is primarily a specific kind of public policy of the state, focused on the activity of religious organizations (religious or confessional associations), that is, communities whose purpose is to confess and spread religious faith (within the meaning of each religion), having their own hierarchy, doctrine and object of worship. The essence of politics is therefore shaping the relationship of the state with individual religious organizations, but also influencing the relations between them.

The religious policy of the state includes activities of a conceptual, program, operational and executive nature, implemented by specialized entities of state power towards religious entities. Under the conditions of a democratic state, they are administrative institutions (independent, e.g. in the form of an office or ministry, or being part of a wider structure, e.g. a department within the ministry) and special services (e.g. monitoring the activities of religious fundamentalists or destructive sects). In authoritarian and totalitarian countries, the subject pursuing denominational policy may be more complex (e.g. apart from state structures, party structures have a decisive status, and extended special services also play a greater role).

Religious policy is conditioned by a number of factors, among which the following can be distinguished: internal (e.g. the specificity and the religious structure of the state, the political system, the ideology prevailing in the state, the pragmatics of political struggle, the legal and systemic religious model of the state, the relationships between the ethno-cultural and religious identifications) and external (e.g. state security considerations, the nature of religious policy within the international environment, geopolitical conditions, international legal norms in which the said state participates, the scale and nature of international "networking" of a given religious community).

Among the varieties of religious policy the following can be distinguished: the religious policy of the concession (practically unrestricted, with the activities of a religious association state-supported or at 
least approved), the religious policy of rationalizing (consent of the state to the basic activity of religious associations, directed mainly at the faithful of their own community and consent to limited external activity) and the religious policy of liquidation (counteracting the negatively evaluated tendencies and phenomena occurring in the activities of a religious organization, or even attempts at its delegalisation and complete eradication). The religious policy of the state is most often considered as a component of internal policy, however, it may also be an important component of foreign policy.

Keywords: religious policy, political science of religion, politology of religion, religious policy of the concession, religious policy of rationalizing, religious policy of liquidation

\section{BIOGRAM}

Ryszard Michalak, prof. nadzw. dr hab. nauk społecznych w dyscyplinie nauki o polityce, specjalność: polityka wyznaniowa. Profesor nadzwyczajny w Instytucie Politologii Uniwersytetu Zielonogórskiego. Autor publikacji naukowych w obszarach: polityki wyznaniowej, problematyki religijno-politycznej w Europie oraz teorii politologii religii. Kontakt e-mail: ryszardmichalak@interia.pl. 